\title{
ACUTE MYELOID LEUKAEMIA IN ONE OF IDENTICAL TWINS
}

\author{
BY \\ C. E. KELLETT, M.D., M.R.C.P. \\ (The Royal Victoria Infirmary, Newcastle-on-Tyne.)
}

Joseph Needham ${ }^{1}$ has recently observed that ${ }^{6}$ progress in science consists not so much of finding the right answers to certain definite and sensible questions, as of deciding what questions are sensible, and of making them definite.' In clinical medicine this is as a rule by no means easy, for cases occur in a haphazard manner in populations subjected to a variety of external influences which will not admit of more than partial investigation, and in the vast majority of such cases the ' control,' which is such an essential factor in all biological experimentation, is inevitably lacking. The following case of acute leukaemia has therefore seemed worth placing on record in so far as it occurred in a family who lived for generations in a sparsely populated moorland, who are of inbred stock, and moreover in one of a pair of identical twins. No new etiological theory has emerged from the study of this case, but it can be claimed that as a result of this and other similar cases many urgent questions now vague and conjectural will admit of a clearer definition.

\section{Case record}

Louie G., aged fourteen-and-a-half years, was admitted to the Royal Victoria Infirmary under Dr. George Hall on January 12, 1937. She is one of a pair of twins who came second in a family of five children, the oldest being a girl aged sixteen who lives with her grandmother, and the other two a boy of thirteen and a girl of seven. The twins were $3 \frac{1}{2} \mathrm{lb}$. each when born, and at one-and-a-half years both caught measles, the progress of the disease being the same in each of them. Shortly afterwards they both caught whooping cough and again the picture of the disease was similar. They remained well until they were eight years old when both had chicken pox, but this time Louie caught the infection in January and her twin sister not until April, though again the course of the disease was similar in the two. They remained well until last year when Leah had mumps in November and Louie a month later in December. For six months prior to this, however, Louie had been unwell; had complained of headaches and lost her appetite, had had fainting attacks and gradually lost colour. Three times prior to admission she had prolonged epistaxis. Her twin sister on the other hand remained well. The family have lived for several generations at Allendale, and for the past seven years have not been away from their home, which is on Lord Allendale's estate some ten minutes' walk from the small village of Carshields. Five weeks prior to admission Louie had however been sent to Allentown to live with her aunt in the hope that the change might benefit her, 


\begin{tabular}{|c|c|c|c|c|c|c|c|c|}
\hline 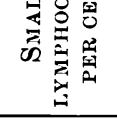 & 1 & 1 & 1 & 1 & 1 & 1 & 1 & 1 \\
\hline 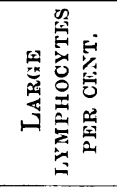 & 1 & 1 & 1 & 1 & 1 & 1 & 1 & 1 \\
\hline 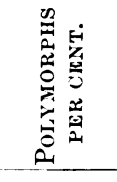 & 18 & $a$ & 1 & 1 & 1 & $\rightarrow$ & ه & 1 \\
\hline 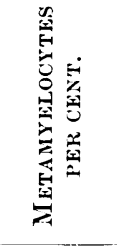 & - & 1 & I. & N & $N$ & - & 1 & - \\
\hline 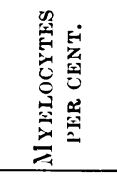 & - & - & 1 & - & - & - & - & $\neg$ \\
\hline 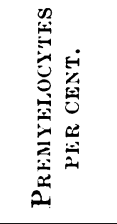 & $\propto$ & $\infty$ & 1 & $\infty$ & - & 1 & 1 & 1 \\
\hline 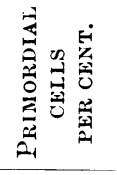 & 8 & 18 & $!$ & SO & $\mathscr{8}$ & S & s。 & $\stackrel{\infty}{\infty}$ \\
\hline 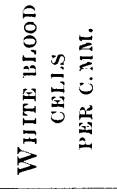 & 总 & 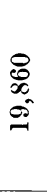 & 1 & $\begin{array}{l}\stackrel{\Xi}{\Xi} \\
\text { î }\end{array}$ & $\begin{array}{l}8 \\
\stackrel{0}{0} \\
\stackrel{0}{8}\end{array}$ & $\begin{array}{l}\stackrel{8}{\circ} \\
\stackrel{\infty}{\infty}\end{array}$ & $\begin{array}{l}8 \\
0 \\
0 \\
=\end{array}$ & 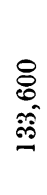 \\
\hline 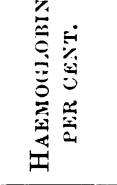 & : & : & 1 & $\curvearrowright$ & $\stackrel{\sim}{*}$ & $\stackrel{\infty}{\sim}$ & స & ๑ิ \\
\hline 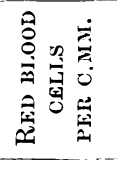 & 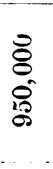 & $\begin{array}{l}8 \\
8 \\
8 \\
8 \\
8\end{array}$ & 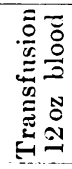 & $\begin{array}{l}8 \\
8 \\
8\end{array}$ & $\begin{array}{l}8 \\
8 \\
8\end{array}$ & $\begin{array}{l}8 \\
8 \\
8 \\
8\end{array}$ & $\begin{array}{l}8 \\
0 \\
\stackrel{0}{0}\end{array}$ & $\begin{array}{l}8 \\
8 \\
8\end{array}$ \\
\hline$\stackrel{\vec{A}}{A}$ & $\begin{array}{l}1 \\
m \\
m\end{array}$ & $\begin{array}{l}\hat{\infty} \\
\vec{\infty} \\
\dot{a}\end{array}$ & $\begin{array}{l}5 \\
\dot{0} \\
\dot{9}\end{array}$ & $\begin{array}{l}5 \\
\infty \\
\infty \\
\vdots\end{array}$ & $\begin{array}{l}\hat{\infty} \\
:= \\
+\end{array}$ & $\begin{array}{l}10 \\
0 \\
:= \\
20\end{array}$ & \begin{tabular}{l}
$\hat{\infty}$ \\
$:=$ \\
\multirow{ส}{*}{}
\end{tabular} & \begin{tabular}{l}
$\hat{\infty}$ \\
$: \approx$ \\
\multirow{N}{*}{}
\end{tabular} \\
\hline
\end{tabular}


On admission she was found to be of good general physique but pale. She appeared recently to have been bleeding from a sore lip, but her mouth was clean. No purpuric haemorrhages were present, her spleen was not palpable, and she had no enlargement of her lymphatic glands. Her blood picture is summarized in table 1 , and even at this stage was remarkable in so far that most of the white cells were exceedingly primitive and the red blood cells showed evidence of an equally gross disturbance.

Six days after admission she began to bleed extensively from the nose and seemed likely not to survive the night. She was given a blood transfusion of 12 ounces, and appeared for a time to have made a remarkable recovery, though, as shown in the table, her blood picture steadily became worse. At about this time the edge of her spleen was just palpable. She had moveover developed a small boil on the middle finger of her right hand, and following this the glands in her right axilla became enlarged and remained so. Her pulse rate, which had throughout been rapid, dropped for a time after the transfusion, as did her temperature, and for two or three weeks there was little change in her condition apart from a steady increase in the count of white cells. She then began to go rapidly downhill and her spleen became enormous, reaching down to well below the umbilicus and at this stage her parents decided to take her home in order that she might die there. She lived for a further week and a day, lying propped up in bed. Three days before her death she began to bleed from her nose again, and from that time on could only take cold water, which she took in large quantities. She complained bitterly of her head, and at times was unconscious. About two hours before she died all the pillows were removed from behind her and she lay down quite flat and appeared to have become unconscious, dying peacefully as if in her sleep. Vital staining of the white blood cells shortly before she died revealed that a considerable proportion of these cells were immature myelocytes.

Throughout this time Leah, her sister, enjoyed excellent health; from time to time she has been examined, and her blood picture has remained normal. The last count taken on April 28, 1937, was as follows : Red corpuscles, $5,200,000$; haemoglobin, 85 per cent.; leucocytes, 5,600; of these 60 per cent. were polymorphs, 2 per cent. basophils, 10 per cent. large lymphocytes, 23 per cent. small lymphocytes and 2 per cent. monocytes.

\section{Family record}

As the photographs show, Louie strikingly resembled her twin sister Leah (fig. I, A, B, C and D). They both wore glasses and their refractive errors were, as shown, virtually the same. A 'casual examination' of their finger prints here reproduced (fig. 2) together with certain measurements can leave no doubt that they amply fulfil Stock's criteria, and should therefore be considered as being identical uni-ovular twins.

The family history can be traced back on the mother's side to her great grandparents. Her great grandmother at 79 is alive and well; her great grandfather died at 70 from a stroke. They had five children, of whom three are alive and well, and two, including the child's grandparent, dead, her grandfather having died of tuberculosis at the age of 41 and her grandmother also of tuberculosis at the age of 23. One of her great-aunts had twins, boys now aged 17. These and the twelve other members of this generation are alive and well. Her mother and her two uncles are alive and well, as are her own sisters and brothers. On the mother's side it has not been possible to discover any example either of leukaemia or, which is probably more significant, of malignant disease, and this would appear to be true of her father's si le of the family. Her paternal grandparents both died over 


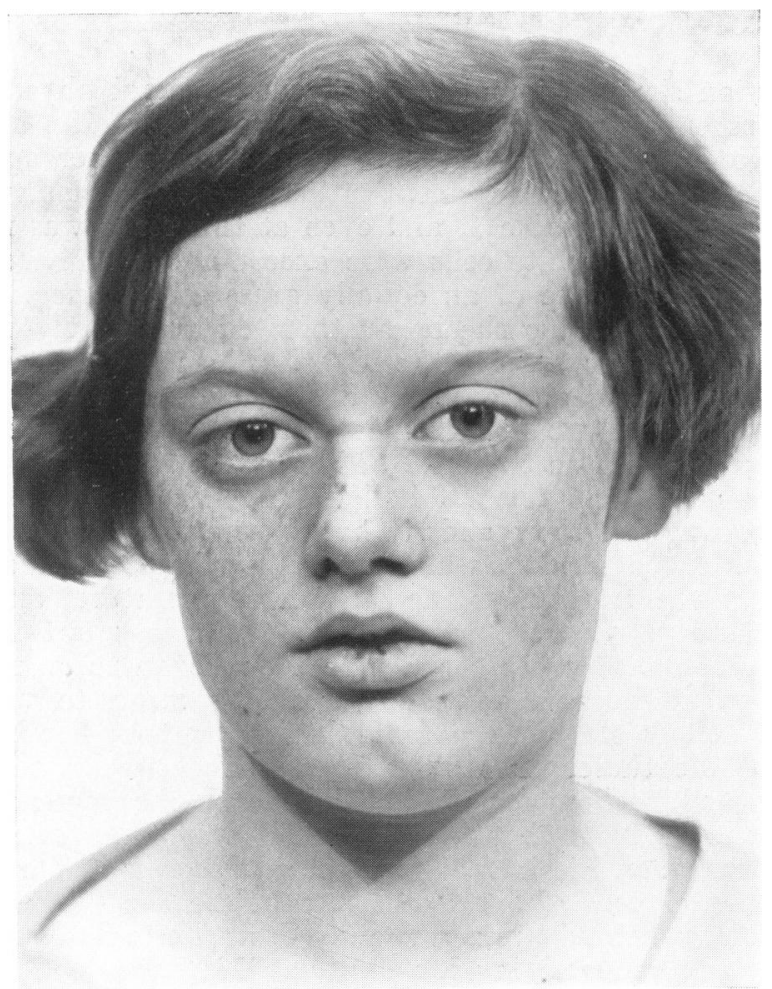

Fig. 1 A.-Patient Louie G.

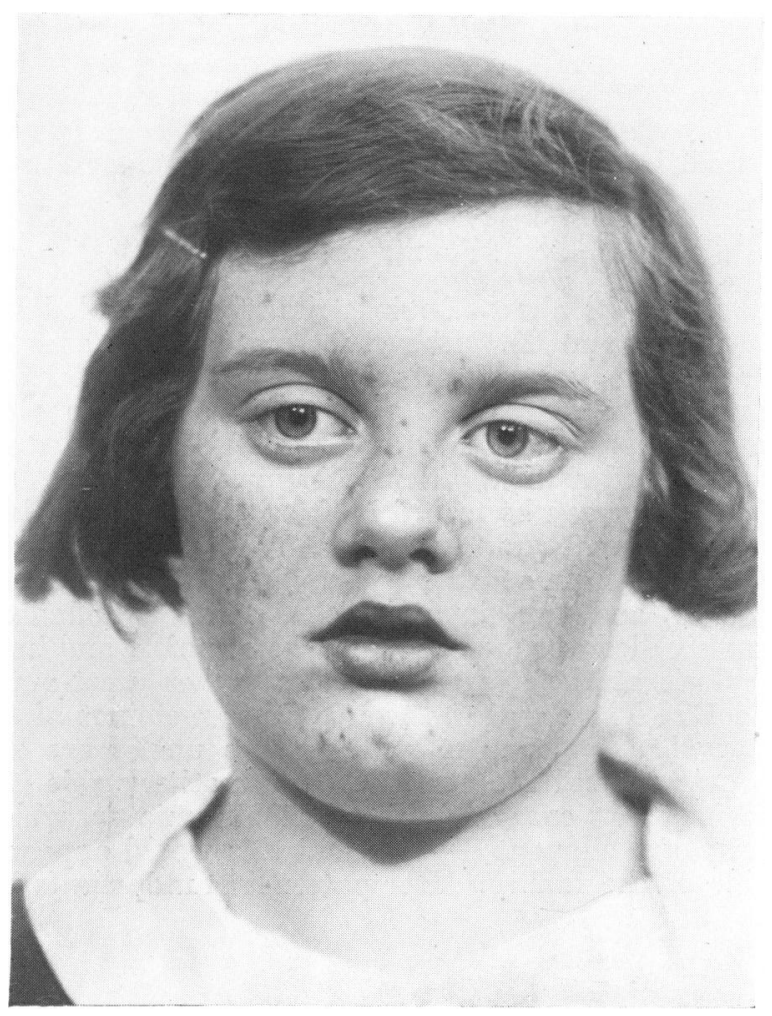

Fig. 1 B.-Twin sister Leah G, 


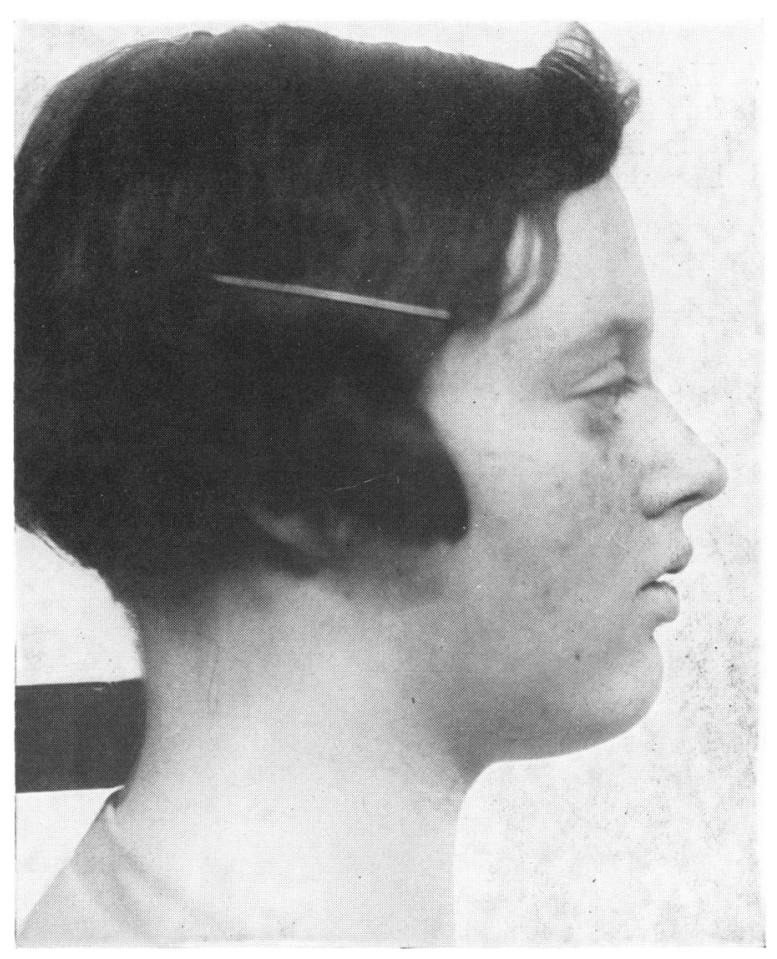

Fig. 1 D.--Leah G. 
the age of 70. Her bachelor uncle is 49 and her spinster aunt is 47 , and a married uncle has five children who are also alive and well as are also her own parents. It is interesting to note that Louie's great-aunt who had twins married her paternal grandmother's brother. Apart from this no

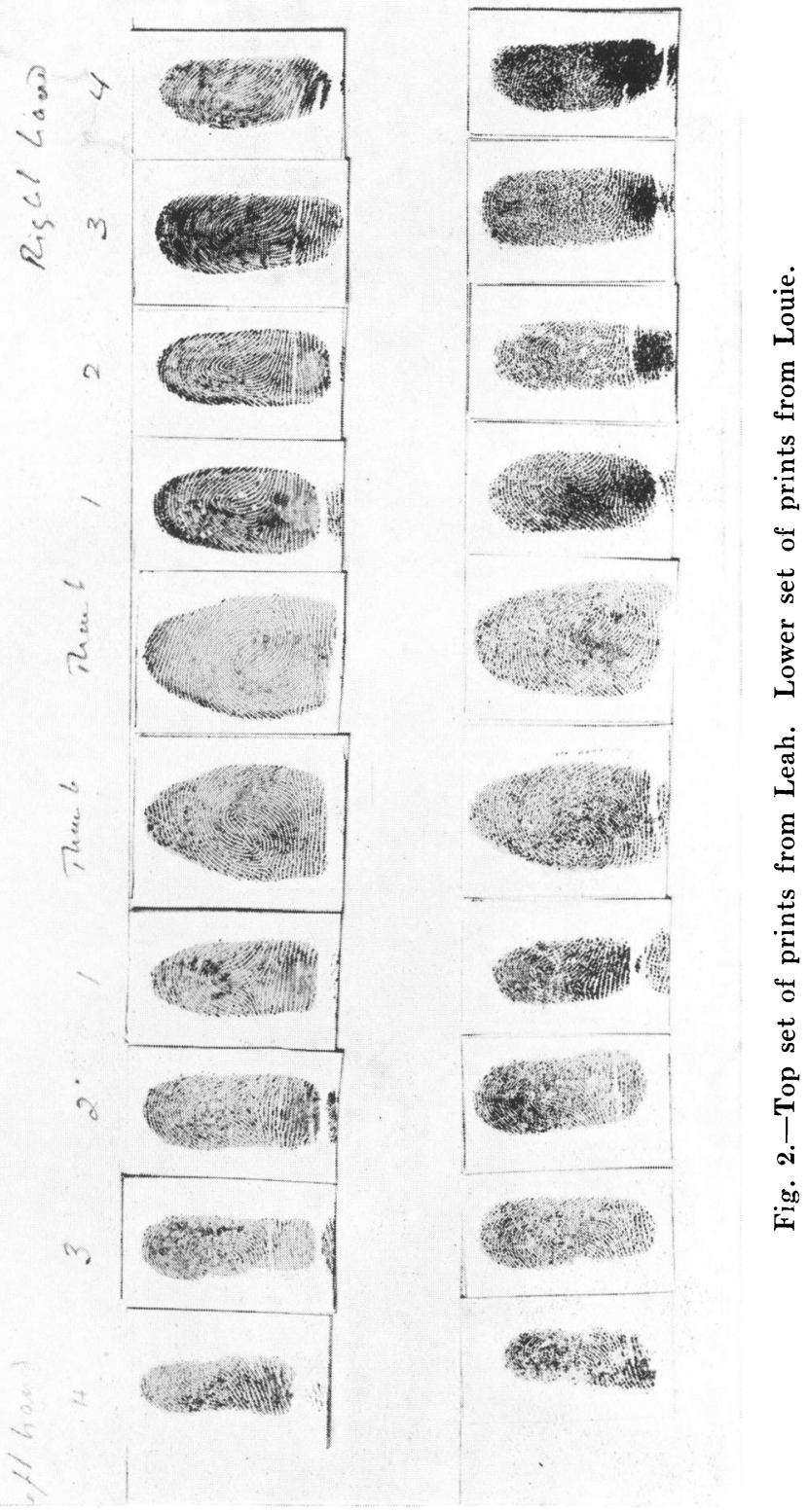

other inter-marriage appears to have taken place between the two families, though since they are Dales folk it is probable that the stock has interbred for many previous generations. 
TABLE 2.

Measurements of twins.

Skull, length.

Skull, breadth.

$175.0 \mathrm{~mm}$.

LOUIE

LEAH

$147.5 \mathrm{~mm}$.

$146.0 \mathrm{~mm}$.

Skull, circumference

$530.0 \mathrm{~mm}$.

$52.5 \mathrm{~mm}$.

$\mathrm{mm}$.

Interpupillary distance.

R.E. $-8.0 /-1.0$

52.5 m.m.

Refractive errors of

eyes. As determined

from their glasses.

$$
\begin{array}{cc}
\text { L.E. }-8.0 /-1.0 & \text { L.E. }-8.0 /-2.0 \\
135 . & 180 .
\end{array}
$$$$
\text { R.E. }-8.0 /-2.0
$$$$
20 .
$$

Colour of eyes and hair identical. Whorl of head hair both clockwise. Both right handed and both belonging to blood group 2.

\section{Discussion}

While nothing definite is at present known of the etiology of the acute leukaemias, and it is still doubtful whether these conditions should be regarded as neoplastic, certain hypotheses have from time to time been advanced which would seem to cover the whole possible etiological field. It has been suggested that the condition may virtually arise independently from external factors, as an expression of an inherited pre-disposition; or else alternatively that it arises as a result of some unknown external specific infection; or else again that it arises as a result of the inter-action of both these factors; or finally it is supposed that this condition represents the result of an abnormal inherited response to some common known external stimulus.

The evidence in favour of the first of these hypotheses is in the main based on experimental work carried out in mice. Slye's work ${ }^{2}$ seemed clearly to prove that the genetic basis was a recessive Mendelian gene, but subsequent work by Richter and MacDowell ${ }^{3}$ seems to have shown that while a hereditary factor is of paramount importance the exact method of the transmission is by no means clearly understood, yet in their strain ' from the 18th-23rd generation, about 90 per cent. (omitting doubtful cases) of all mice surviving more than six months developed leukaemia spontaneously.'

So far as work in man has been concerned obvious difficulties present themselves. Considerable intervals of time elapse between successive generations, and it is obviously impossible to obtain by methods of inbreeding a relatively homogenous strain such as the C58 employed by MacDowell and Richter in which inbreeding by brother and sister mating had been carried out for eighteen generations before the start of their investigation. Nevertheless, it is perhaps worth noting that while certain remarkable cancer pedigrees have been reported in man, such as those by Warthin $^{4}$ and Lockhart-Mummery ${ }^{5}$, no such pedigrees have been reported in cases of leukaemia, and examples of familial or hereditary cases of leukaemia 
are actually strikingly few. These cases, eleven in all, have recently been reviewed by Petri $^{6}$, and subsequently added to by Morawitz ${ }^{7}$.

Another method of approach, however, does exist in man, in whom the difficulty of obtaining inbred strains can to some extent be overcome by the use of identical twins, as was noted by Galton ${ }^{8}$ many years ago. Elsewhere $^{9}$ the writer has dwelt on the difficulties underlying the recognition of such twins and the pitfalls inherent in their use; while the whole field of twin pathology has been recently reviewed by Siemens ${ }^{10}$, Margolis and Eisenstein $^{11}$, and Stransky ${ }^{12}$.

While there is as yet no certain method of identifying identical twins, Louie and her twin sister fulfill all the criteria laid down for such twins by Stocks, and in the present state of knowledge it would appear impossible to consider them as being other than homozygous. If that is so it is apparent that the acute leukaemia which supervened in Louie could not be a result of the emergence of some purely hereditary factor but that some external factor common to one and not the other must have played some part in its emergence. It would seem furthermore that a greater significance must be attached to this case of twins in which only one of them had the condition than to the apparently only other pair reported by Dameschek ${ }^{13}$ in which both of the twins died after one another at the age of fifty-six from a chronic lymphatic leukaemia, in so far as in such studies negative findings must of necessity be of greater significance than positive ones since twins are obviously affected simultaneously by a variety of infectious disorders in which hereditary predisposition may play no important rôle. It is, however, impossible at this stage to assert that this occurrence of acute leukaemia in one of identical twins implies that hereditary factors play no part in the etiology of the condition. Champlin ${ }^{14}$, for instance, reports an example of twin brothers said to be alike in whom sarcoma of the testis developed in one at the age of twenty-four and in the other at the age of thirty-one. The first one had received a severe knock in the testis some years prior to the occurrence of the sarcoma, and it is not unreasonable therefore to suppose, as Macklin $^{15}$ suggests, that here the emergence of the condition had been accelerated by trauma and that had there been no such trauma a sarcoma might have supervened in both twins simultaneously; as did a fibro-adenoma of the breast in twins reported by Burkard $^{16}$, and an adeno-carcinoma of the uterus in twins reported by Croom $^{17}$; so that twins indeed supply some of the strongest evidence in favour of the hereditary factor underlying neoplastic processes. It should be emphasized that so far as could be determined Louie and her sister had led identical lives and met the same people until the disease became manifest. Consideration therefore of this case does lead to the conclusion that the first of the etiological hypotheses suggested is untenable in this particular instance, but while there remains the hypothesis that the condition is due solely to some external factor or infection, and so far as this case goes some support is lent to this view, it is apparent that it is impossible on 
this case alone to rule out the third hypothesis. This suggests that a leukaemia arises as a result of the interaction of both of these factors but while some believe that the external factor is a specific one there are many who appear to hold that this need not be so.

Poynton, Thursfield, and Paterson ${ }^{18}$, who analyzed eighteen cases of leukaemia, incline to the belief that the solution of the problem lies rather in some peculiar reaction to infection than in the existence of some peculiar specific infective agent, and such cases have been reported by Isak Lundholm $^{19}$ who published a case of staphylococcal sepsis in a girl of threeand-a-half years that apparently developed into an acute lymphatic leukaemia, and Bonciu and Ionesco ${ }^{20}$ who reported the case of a little girl with a haemolytic septicaemia and similar blood changes and discuss at length that conception of Sternberg 'pour qui la leucémie aiguë ne serait qu'une réaction biologique des organes hématopoiétiques provoquée par le streptocoque.' A number of related examples have also been recorded by Donath and $\mathrm{Saxl}^{21}$. Some years ago the writer ${ }^{22}$ analyzed the mode of onset of forty cases of acute myeloid leukaemia and sixty cases of lymphatic leukaemia in childhcod and was unable to find any real support in favour of this theory. In not less than three instances, however, an acute leukaemia was said to have come on following whooping cough, and in two instances following mumps. Both Louie and Leah had whooping cough at about the age two of these children are said to have had it and developed leukaemia, but despite the predisposition which must have been present neither of them seemed to develop anything approaching the leukaemic state. So much might, however, be said of any child who had had pertussis in infancy and subsequently developed a leukaemia. On the other hand, had it not been for the existence of a control it might have been argued in this case that the leukaemic picture had supervened as a result of an attack of mumps even though from her mother's story it seems quite clear that Louie was ill for several months before she contracted mumps. The complete absence of any such change in the blood picture of her sister Leah would seem to rule out this factor, and there can be little doubt that the accumulation of cases similar to these will ultimately dispel the rather vague widespread feeling referred to in the paper already quoted of Bonciu and Ionesco that relates the leukaemias to some sort of peculiar response to a common known infection.

The remaining hypothesis is one which postulates a specific infection. The experiments of Furth $^{23}$ and MacDowell $^{3}$ in transmission of experimental leukaemias in mice suggests that the susceptibility of the host is of the greatest importance. So far as these twins are concerned it must a priori be supposed that their susceptibility is the same. This would suggest that the infectivity of the specific etiological agent cannot be high. In the ordinary sense of the word there is indeed no real evidence of the infectivity of this condition. Mention has already been made of the low familial incidence, and the case reported by $\mathrm{Obrastzow}^{24}$ of infection from patient to 
nurse remains, as Baar and Stransky $^{28}$ remark, unique. Mothers with leukaemia have given birth to healthy children, and the solitary transfusion experiments of Schupfer ${ }^{26}$ from man to man, as well as many experiments of injection into animals, remain negative. On the other hand the occurrence of disease is an exceptionally poor index of infection having occurred, though in this condition it is apparently the only one, for actual disease will occur only in susceptible people. In such circumstances one may argue that while the severity of the epidemic will depend on the numbers of such people and the virulence of the infection, the spread of the infection will be revealed only by the sporadic appearance of the disease. The four cases described by Aubertin and Grellety Bosviel ${ }^{27}$ are therefore possibly of significance, in that they occurred within a few weeks of one another in a relatively restricted area, and with this may possibly be associated the fact that in every instance the leukaemia was exceedingly acute. The resemblance of these cases to the one here described and the relative isolation in which Louie and her family lived encouraged the belief that something might emerge from a study of any cases with which they may even indirectly have had contact.

Enquiries made by the writer, by the patient's family and by her own physician failed to reveal any possible source of such infection; on the other hand a search through the records of the Royal Victoria Infirmary for the past five years yielded information which is probably significant.

\section{A local investigation}

During the past five years sixty-three cases of leukaemia were admitted to the hospital, and during this period approximately thirty-two persons per million per year are reported as having died of the condition according to the Registrar-General's figures. In this condition the incidence rate must approximate closely to the mortality rate, and it is therefore possible to arrive at a rough estimate of the number of cases that are likely to have occurred in this area and of the proportion sent on to this hospital. Now the maximum population of this area from which the Royal Victoria Infirmary draws its patients is probably less than 1,750,000 persons (Northumberland 756,782; Durham-less Sunderland, Darlington and the Hartlepools-1,160,131), so that it would appear that a significant proportion of all cases of leukaemia occurring in this area pass through this institution. This population is from an epidemiological point of view conveniently distributed in the main within a few miles of Newcastle, thus constituting a large ' reservoir,' and then scattered in varying sized communities and at times extremly sparsely over a wide area.

In such circumstances if this condition be really due to some external infection as a study of these twins demanded then it might reasonably be hoped to demonstrate a rather constant emergence of this condition in a sporadic manner in the main reservoir and from time the appearance of the condition in virtually epidemic proportions in one or other of the outlying 
communities, particularly if the outlying community be not too sparsely populated. Such a distribution on the other hand would be unlikely to arise if the condition were due to some other factor.

For the purposes of this investigation a point was chosen in an arbitrary manner approximately halfway between Newcastle and Sunderland, and a circle drawn around this point having a radius of eight miles. This circle included approximately 29,610 acres of the 1,291,978 acres of Northumberland and of 462,079 of the 746,096 persons living in the County at the time of the 1931 census, and 97,783 acres of the $649,4,20$ acres of Durham and 711,010 of its $1,486,175$ inhabitants; it is apparent that about half the population of the two counties live within this arbitrarily chosen rather restricted area. The communities without this area consist. in the main of mining villages living under very similar conditions and agricultural communities, often very diffusely scattered, who are on the whole strictly comparable.

Of the sixty-three cases of leukaemia admitted from 1932-1936 inclusive, eleven were classified under the heading of acute myeloblastic leukaemia. Of these, five arose at approximately yearly intervals within the central area in an entirely sporadic manner at considerable distances from one another, the remaining six from without this area. In marked contrast to the five cases within the area these cases, with the exception of one case which occurred apparently sporadically at Tudhoe, Spennymoor, in 1935, a large mining village some twenty miles south of Newcastle, occurred under what, on analysis, appeared to be almost epidemic conditions, three at or near Ashington, a large mining village some twenty miles north of Newcastle and two west of Newcastle in the very area from which the case reported in the twin occurred. In so far however as the latter group are in a rural area, the Hexham R.D., which has a population of 21,306 , an acreage of 196,812 , and a density of 0.11 persons per acre, the inter-relation of the cases is less definite than at Ashington, where the density in the Hirst ward where the cases occurred for the most part is 29.0 persons per acre, the acreage being 676, and persons 19,623, that of Ashington as a whole being $9 \cdot 7$, the acreage being 3,309 and the population 29,418 .

Of the twenty-five cases of chronic myeloid leukaemia fifteen occurred within the area and ten without; one of these occurred at Ashington at the time the epidemic began, and one again in 1936 within six miles of Louie, apart from these two, the cases appeared to arise sporadically, and no other cases appeared in these two particular ' epidemic areas.'

Of the thirteen cases of acute lymphatic leukaemia six occurred within the area and seven without; so far as they could be determined they arose in a sporadic manner; one case however of acute lymphatic leukaemia came from Ashington from the same street and at the same time as a case of acute myeloid luekaemia; no other case came from this area under the rest of the period under review. Of the fourteen cases of chronic lymphatic 
leukaemia only four came from within the area and ten from without, one of these again coming from Ashington*; so far as could be determined these cases all arose in a sporadic manner.

So far as it goes this investigation into the hospital records proved more helpful than might have been anticipated, though it must be emphasized that none of the epidemiological data so ascertained have the clear cut quality of that derived from a study of the twins. This investigation not only supplied a possible source for Louie's infection but also some slender support for the explanation tentatively advanced to the issues her case had so clearly raised. For H. C., a young man of twenty-three, who lived at Slaley in the same sparsely populated area as Louie some fifteen miles away from her and died of an acute myeloid leukaemia in Professor Hume's wards on November 17, 1936, had been ill since April, and being a motor driver had the relatively wide range of action essential if he were to act as a vector in an area with a density of $0 \cdot 11$ persons per acre, while the concentration of cases such as occurred at Ashington lent some support for the contention that Louie's condition had arisen from some external infection, widespread possibly, but since her identical twin escaped, of such low infectivity as to suggest the intervention of a second factor such as an insect vector.

\section{Summary}

A case of acute myeloid leukaemia is described in one of identical twins. It is pointed out that this case raises certain clear cut issues that can be best met by the assumption that her condition arose as a result of the action of some external factor, specific, but of low infectivity. An analysis of the cases of leukaemia admitted into the Royal Victoria Infirmary over the past five years yielded information that tended to support such an assumption.

Thanks are due to Dr. George Hall for his permission to publish details of this case admitted under his care, and to the Honorary Staff and Department of Pathology of the hospital for permission to make use of their material.

\section{Appendix}

SUMMaRy OF CASES OF LEUKaEmIa ADMITTED FROM Ashington aND ITS VICINITY INTO THE ROYAL VICTORIA INFIRMARY FROM 1932 To 1936 INCLUSIVE

H. D., age 19, from Ashington, was admitted on August 31, 1932, with a history of frequent epistaxis and weakness since March of that year, which had been relieved in May on the occasion of her first admission by deep $\mathrm{x}$-ray therapy, under Dr. Parkin. Her spleen and lymph glands were enlarged, she had 2,400,000 R.B.C. and 150,000 W.B.C. per c.mm., and a differential count of $17 \cdot 5$ per cent. myeloblasts, 24.5 per cent. pre-myelocytes, 7 per cent. neutrophil myelocytes, 7 per cent. neutrophil meta-myelocytes,

* This patient, A.M., appears on re-examination of her autopsy preparations to have been an undoubted case of sub-acute myeloid leukaemia. 
19.5 per cent. polymorphs, 12.5 per cent. basophils, 1 per cent. eosinophils, 9.5 per cent. lymphocytes, 1.5 per cent. monocytes. She died September 14,1932 , and autopsy revealed findings characteristic of a sub-acute myeloid leukaemia. (Differential count and autopsy done by Professor Bernard Shaw.)

G. P., age 43, from Ashington, was admitted December 5, 1932, under Dr. Drummond with a history of sudden extensive bruising of his left leg and right arm since November 16, 1932. He had 1,540,000 R.B.C. and 30,000 W.B.C. per c.mm., and of these 99 per cent. were myeloblasts and pre-myelocytes. He died December 19, 1932, and autopsy revealed findings characteristic of an acute myeloblastic leukaemia. (Differential count and autopsy done by Professor Bernard Shaw.)

J.W.L., age 16, from Ashington, was admitted January 13, 1933, under Dr. Hall with a history of prolonged haemorrhage following tooth extraction on January 1, 1933. A blood film ' resembled a bone marrow film,' and the immature cells were thought to be lymphoblasts. He died January 16, 1933, and the autopsy revealed findings typical of an acute leukaemia. (Autopsy by Professor Bernard Shaw; microscopic preparations not made.)

J. Q., age 34, from Ashington, was admitted under Dr. Drummond, January 7,1934 . 'He gave a three weeks' history of 'lumps and rheumatics down the left side.' His spleen was enlarged to his umbilicus, he had $2,500,000$ R.B.C. and 400,000 W.B.C. per c.mm. The blood film was typical of a myeloid leukaemia. He died January 18, 1934, there was no autopsy.

A. M., age 41, from Ashington, was admitted under Professor Hume, July 15, 1935. She complained of weakness since Christmas, 1934, and of prolonged bleeding following the extraction of some teeth a month prior to admission. Petechiae were present, the lymph glands were not enlarged, the spleen not felt. She had 35,000 W.B.C. per c.mm. of which the great majority were very primitive. These were thought to be lymphoblasts, a subsequent review of the material obtained at autopsy (she died August 9, 1935), by Dr. J. G. Thomson, revealed the presence of a number of myelocytes and it would appear almost certain this was a case of sub-acute myelogenous leukaemia.

L. S., age 44, from a small village 10 miles north of Ashington, was admitted September 10, 1936, under Dr. Nattrass. She had been out of sorts for one year, and had had ready bruising and pallor for about two months. Her spleen was found to be slightly enlarged; she had 1,650,000 R.B.C. and 3,600 W.B.C. per c.mm., of these 75 per cent. were classed as primordial, 4 per cent. as myeloblasts, 6 per cent. as meta-myelocytes, 6 per cent. as polymorphs, 1 per cent. as monocytes, 3 per cent as lymphocytes and 1 per cent. as unclassified. She had three transfusions and died about fourteen days after returning home. (Differential count by Dr. J. G. Thomson.)

\section{REFERENCES}

1. Needham, J., Proc. Roy. Soc. Med., London, 1936, XXXIX, 1577.

2. Slye, Maud, Am. J. Cancer, New York, 1931, XV, 1361.

3. Richter, M. N., \& MacDowell, E. C., Physiol. Rev., Baltimore, 1935, XV, 509.

4. Warthin, A. S., J. Cancer Res., New York, 1925, IX, 279.

5. Lockhart-Mummery, P., Lancet, London, 1925, i, 427.

6. Petri, S., Acta path. et microbiol. Scand., Copenhagen, 1933, X, 330.

7. Morawitz, P., München. med. Wchnschr., Munich, 1933, LXXX, 1201.

8. Galton, F., J. Anthrop. Inst., London, 1876, V, 324 \& 391. 
9. Kellett, C. E., Arch. Dis. Childh., London, 1933, VIII, 279.

10. Siemens, H. W., Die Zwillingspathologie, Berlin, 1924.

11. Margolis, H. M., \& Eisenstein, V. W., Ann. Int. Med., Chicago, 1933, VI, 1489.

12. Stransky, E., Rev. franc. de pediat., Paris, 1934, X, 159.

13. Dameschek, W., Savitz, H. A., \& Arbor, V., J. Am. Med. Ass., Chicago, 1929, XCII, 1348.

14. Champlin, H. W., ibid., 1930, XCV, 96.

15. Macklin, M. T., Quart. Rev. Biol., Baltimore, 1932, VII, 255.

16. Burkard, H., J. Am. Med. Ass., Chicago, 1922, LXXVIII, 1762.

17. Croom, quoted by Murray, G. R., Lancet, London, 1925, i, 529.

18. Poynton, F. J., Thursfield, H., \& Paterson, D., Brit. J. Child. Dis., London, 1922, XIX, 128.

19. Lundholm, I., Acta Paediat., Stockholm, 1930, IX, 137.

20. Bonciu, O., \& Ionesco, V.T., Arch. roumaines de Path. Exp., Paris, 1930, III, 65.

21. Donath, F., \& Saxl, P., Die Septischen Erkrankungen in der Inn. Med., Vienna, 1929.

22. Kellett, C. E., Arch. Dis. Childh., London, 1932, VII, 263.

23. Furth, J., Seibold, H. R., \& Rathbone, R. R., Am. J. Cancer, 1933, XIX, 521.

24. Obrastzow, Deutsche med Wchnschr., Leipzig, 1890, XVI, 1150.

25. Baar, H., \& Stransky, E., Die Klinische Haematologie des Kindesalters, Vienna, 1928, 247.

26. Schupfer, F., Riforma Med., Naples, 1905, XXI, 589, 623, 650.

27. Aubertin, C., \& Grellety Bosviel, P., Arch. mal. du coeur, Paris, 1923, XVI, 696. 